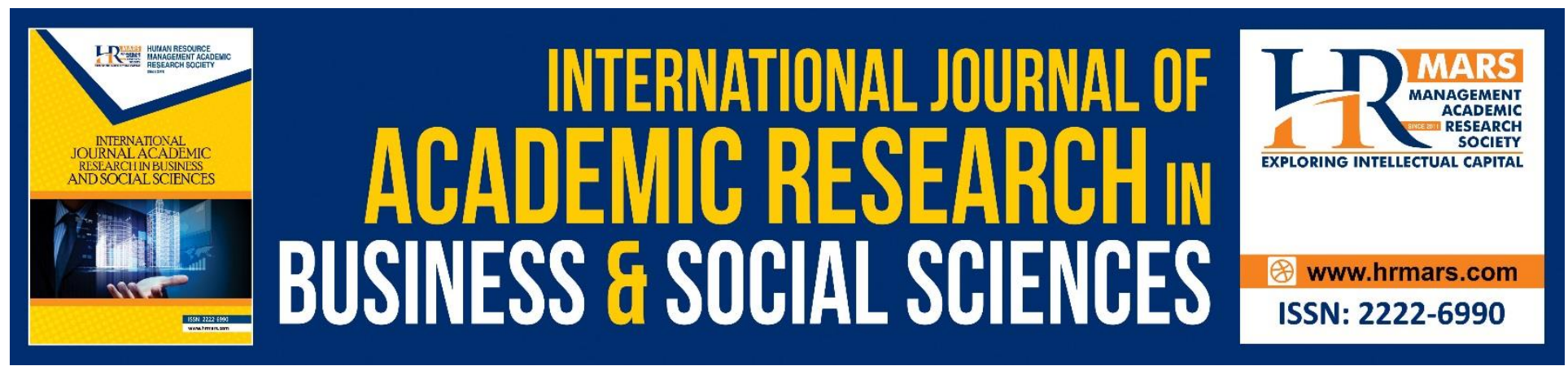

\title{
Translation and validation of the Treatment Motivation Questionnaire (TMQ) to Malay Version
}

Engku Mardiah Engku Kamarudin, Zaida Nor Zainudin, Yusni Mohamad Yusop, Amelia Mohd Noor, Mohd Izwan Mahmud

To Link this Article: http://dx.doi.org/10.6007/IJARBSS/v11-i7/10365 DOI:10.6007/IJARBSS/v11-i7/10365

Received: 18 May 2021, Revised: 21 June 2021, Accepted: 09 July 2021

Published Online: 28 July 2021

In-Text Citation: (Kamarudin et al., 2021)

To Cite this Article: Kamarudin, E. M. E., Zainudin, Z. N., Yusop, Y. M., Noor, A. M., \& Mahmud, M. I. (2021). Translation and validation of the Treatment Motivation Questionnaire (TMQ) to Malay Version. International Journal of Academic Research in Business and Social Sciences, 11(7), 1297-1311.

\section{Copyright: (C) 2021 The Author(s)}

Published by Human Resource Management Academic Research Society (www.hrmars.com)

This article is published under the Creative Commons Attribution (CC BY 4.0) license. Anyone may reproduce, distribute, translate and create derivative works of this article (for both commercial and non-commercial purposes), subject to full attribution to the original publication and authors. The full terms of this license may be seen at: http://creativecommons.org/licences/by/4.0/legalcode

Vol. 11, No. 7, 2021, Pg. 1297 - 1311

Full Terms \& Conditions of access and use can be found at http://hrmars.com/index.php/pages/detail/publication-ethics 


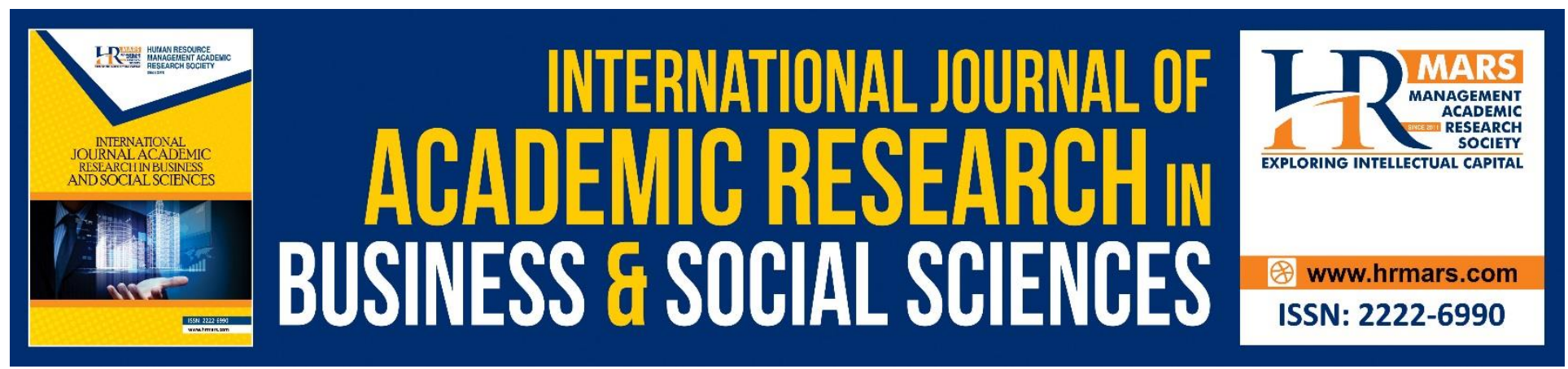

\title{
Translation and validation of the Treatment Motivation Questionnaire (TMQ) to Malay Version
}

\author{
Engku Mardiah Engku Kamarudin ${ }^{1}$, Zaida Nor Zainudin ${ }^{1}$, Yusni \\ Mohamad Yusop', Amelia Mohd Noor², Mohd Izwan Mahmud ${ }^{3}$ \\ ${ }^{1}$ Universiti Putra Malaysia, Malaysia, ${ }^{2}$ Universiti Perguruan Sultan Idris, Malaysia, ${ }^{3}$ Universiti \\ Kebangsaan Malaysia, Malaysia \\ Email: engkumardiah@upm.edu.my
}

\begin{abstract}
Introduction: Motivation plays a significant role in treating any illness, especially for patients with addiction problems. Moreover, motivation is a factor that influences patients to look for treatment possibilities, follow instructions of the treatment, and mainly make prosperous longterm changes.

Objective: The purposes of this study are to translate and validate the Malay version of the Treatment Motivation Questionnaire (TMQ) among opioid use disorders in Methadone treatment. This questionnaire is to study patient's motivation for entering treatment.

Method: Translation, back-translation, pilot testing, and validation of the final TMQ were all part of the four-phase technique for translating and validating generic questionnaires. The intercorrelation item and the Cronbach's alpha coefficient were used to assess the final TMQ's overall internal consistency.

Results: The Malay TMQ had excellent Cronbach's alpha values of 0.942. In addition, it had a good factor loading values for most items except one item under 'confidence in treatment' $(r=0.0082)$ and eliminating that item from scoring increased the alpha coefficient of the scale of TMQ. Correlations among scales were between .616 and .96 .

Conclusions: This study demonstrates that the Malay version of the TMQ is a valid and reliable tool used to measure treatment motivation in Malay-speaking populations.

Keywords: Treatment Motivation Questionnaire, Translation, Validation, Opioid Use Disorder, Methadone

\section{Introduction}

Treatment motivation is demonstrated to significantly correlate to treatment commitment, retention, and an essential factor in the substance abuser's readiness for treatment and treatment success (Cahill et al., 2003). Treatment motivation, defined as the ability to accept and be ready for change, can vary depending on the time and situation (Bulut \& Bozkurt, 2019). High
\end{abstract}


treatment motivation predicts lower relapse, retention and produces better treatment outcomes (Dillon et al., 2016; Wild et al., 2016) found that clients with low internal motivation at the beginning of admission may drop out early; client users who require high intrinsic motivation are great for use with high cognitive commitment.

The drug users' psychological experience is a crucial factor determining whether they will turn to drugs or quit them. The fulfilment of the psychological needs constitutes drug users' internal motivation, which drives them to quit drugs and pursue healthy development (Chan et al., 2019). However, some of the research found that motivation is still a challenge when most of those who recover from drug rehabilitation treatment will return to their original habit of drug addiction (Wegman et al., 2017) due to craving urges. In addition, studies showed that the drugseeking behavior (Almeman, Ismail \& Mohamad, 2017) cause high dropout in Methadone treatment (Hong et al., 2017), and the invitation of old friends as well as the inability to cope with stress (Salleh, 2012).

According to Melemis (2010), motivation is part of the significant intrinsic factors contributing to relapse. He explained three levels of drug treatment difficulty: i) the importance of the motivation to change, ii) the behavior change to stop drugs, and iii) the desire to maintain recovery. Besides Methadone treatment, a psychological approach is an established approach in covering the intrinsic issues. For example, the results of a local study of Ibrahim et al (2012) found that negative emotions, social stress, and personal conflict of the addict who has recovered can lead to a drug addict returning to drug use.

Existing literature broadly illustrates the causes of drug abuse and relapse (Mohamad et al., 2014; Robson et al., 2015). Drug relapse causes are divided chiefly into individual variables and social/environmental factors (Chan et al., 2019; Miller \& Carroll, 2011). Individual differences, such as gender, co-occurring drug use, early trauma and adversity, history of drug use (Wemm \& Sinha, 2019), and low self-control and self-determination, are important individual determinants (Chan et al., 2019). Addicts who currently are not seeking or receiving treatment have fewer self-reported psychological, social, and drug-use problems than those in treatment. These discrepancies could be due to (a) a lack of self-awareness among untreated participants or (b) more immediate motivations for seeking treatment among those under treatment (Ayres et al., 2014; Scherbaum \& Specka, 2008) found that interventions using motivational interviewing based on self-determination theory affected improvement in health and self, crime reduction, stress, and drug use. Greater motivation also occurred in the participants, and this range of motivations increased self-efficacy and helped in the cognitive confusion that arose. Similarly, the study by Chan et al (2019) used the theory of self-determination as a framework to examine the psychological experiences of drug addicts and their decision to take drugs or not, with particular emphasis on the concept of relativity.

In recognition of the need for operational definition, the Treatment Motivation Questionnaire (TMQ) based on self-determination theory (Deci \& Ryan, 1987) was used in this study. This instrument determines four domains of motivation: internal motivation, external motivation, help-seeking, and confidence in treatment (Cahill et al., 2003; Millere et al., 2014). However, until recently, there was no study examining the validity of the TMQ in a Malay speakers population. Therefore, this study examines the translation and validity of the TMQ in screening for treatment motivation in a Malay-speaking population of opioid use disorder patients. 


\section{Objectives}

The present study was designed to:

i. translate the Treatment Motivation Questionnaire (TMQ) into Malay version.

ii. test the reliability and internal consistency of the TMQ Malay version.

iii. explore the structural validation of the TMQ Malay version.

\section{Methodology}

\section{Study Design}

This study applied a quantitative observational cross-sectional in this study.

\section{Data Collection}

Ninety participants were selected randomly from five Methadone Clinics under the purview of the Ministry of Health (MOH), Malaysia. To be eligible for treatment, participants should meet the diagnosis for Opioid Use Disorder (moderate or severe) based on DSM-5 criteria (APA, 2013). In addition, the following inclusion criteria for participants are listed below:

1. The patient is above 18 years old.

2. The patient received at least three months of treatment with Methadone.

3. The researchers have obtained consent and cooperation for voluntary intervention.

4. The participants do not have chronic mental illnesses such as schizophrenia and bipolar disorder.

5. If the patient has a chronic infectious disease, such as HIV/AIDS and tuberculosis (TB), they should be admitted until they are stable, under the care and supervision.

The administration of TMQ consistently decreases the risk of assessment bias by the trained research assistants. Participants need to fill up the TMQ questionnaires within 30 minutes. Sociodemographic data, i.e., education, occupation, and status, were also collected using customized data collection forms.

\section{Translation}

We translated the TMQ into the Malay language version after obtaining permission from the developer of the original English translation (Deci \& Ryan, 2000). Forward and two bilingual individuals made backward translations of the questionnaires with counseling backgrounds. First, they independently translated the original English measures into Malay and then combined them into a single Malay translation. Two other bilingual translators then translated back into English. No change was suggested in the back-translated questionnaire and, therefore, satisfied with the Malay translations. In addition, constituting an expert committee is produced the prefinal version of the translation to review all versions of the translations and determine whether the translated and original versions achieve semantic, idiomatic, experiential, and conceptual equivalence (Beaton et al., 2000). Finally, we tested the final Malay translations on 50 candidates as a pilot test to verify the clarity and breadth of the TMQ. To ensure the optimal objective of the translation, the researcher conducted interviews with participants in the pilot project. The results of the latter pilot study revealed that TMQ was clear and understandable to participants. In addition, during the translation process, the researcher considered three aspects i) translation equivalence, ii) conceptual equivalence, and iii) measurement equivalence (metrics) in line with Matsumoto's (1996) suggestion that different cultural backgrounds should have equivalence. 


\section{Validation}

Three addiction therapy professionals fluent in Malay and English checked the content validity. The criteria selection of the experts including having more profound knowledge in addiction therapy, various experiences and produce a comprehensive study in the research in the field. All experts have examined the instrument's construction and each item's level and provided feedback based on the study's objectives.

\section{Reliability}

We tested the reliability of TMQ using internal consistency of the questionnaire by Cronbach's alpha coefficient, and alpha equal to or greater than 0.70 was considered satisfactory (Nunnally, 1994).

\section{Data Analysis}

Data were analyzed using the SPSS version 21.0. The presented descriptive statistical data using mean values, standard deviations, and percentages for the demographic variables. Meanwhile, to assess the relationship between different variables, Pearson's correlation is used. We used Cronbach's alpha coefficients, corrected item-total correlation, and inter-item correlation matrix analysis to assess the internal consistency reliability. A Cronbach's alpha of $\geq 0.7$ and item-total correlation of $>0.2$ was considered statistically acceptable (Nunnally, 1994]. Only statistically significant differences at $\mathrm{p}<0.05$ were reported.

\section{Ethical Consideration}

The ethical approval of the Medical Research and Ethics Committee of the Ministry of Health of Malaysia was obtained on 13 January 2018 (reference number: NMRR-16-2841-32666 (IIR)) to carry out further tests in opioid dependents in five Methadone treatment clinics. Participants signed a written informed consent form before participating in the study.

\section{Results}

We recruited opioid use disorder patients from Methadone clinics in Klang Valley, Malaysia, based on a random selection. We included participants who consented to participate in the study and were able to read and understand Malay. We offered representatives in each clinic a questionnaire to all participants in the methadone clinics and collected it within two weeks. More than $30 \%$ of the participants were between 41 and 50 years old. The participants were almost equally married and single, and only $16 \%$ were widowed/widower. The data showed that the smoking method was more prevalent among participants. In addition, the data showed that participants had attempted to quit substance abuse without treatment before starting methadone treatment. Table 1 shows the demographic profile of the participants. 
Table 1: $\quad$ Demographic profile of the participants.

\begin{tabular}{|c|c|c|c|}
\hline \multirow{2}{*}{ Demographic } & & \multicolumn{2}{|c|}{$\mathrm{N}=90$} \\
\hline & & $f$ & $(\%)$ \\
\hline Gender & Male & 90 & 100 \\
\hline \multirow[t]{5}{*}{ Age } & $21-30$ years & 7 & 7.78 \\
\hline & $31-40$ years & 33 & 36.67 \\
\hline & $41-50$ years & 30 & 33.33 \\
\hline & $51-60$ years & 14 & 15.56 \\
\hline & $61-70$ years & 6 & 6.67 \\
\hline \multirow[t]{3}{*}{ Status } & Single & 42 & 46.67 \\
\hline & Married & 32 & 35.55 \\
\hline & Widow/Widower & 16 & 6.67 \\
\hline \multirow[t]{4}{*}{ Occupation } & Unemployed & 24 & 26.67 \\
\hline & Odd jobs & 35 & 38.89 \\
\hline & Employed & 4 & 4.44 \\
\hline & Business & 27 & 30 \\
\hline \multirow[t]{3}{*}{ Duration of addiction } & 0 - 10 years & 25 & 57.78 \\
\hline & 11 - 20 years & 37 & 41.11 \\
\hline & 21 - 30 years & 28 & 31.11 \\
\hline \multirow[t]{2}{*}{ Use of other illicit drugs } & Yes & 82 & 91.11 \\
\hline & No & 8 & 8.89 \\
\hline \multirow[t]{3}{*}{ Heroin administration } & Smoke (Chase) & 45 & 50 \\
\hline & Intravenous & 40 & 44.44 \\
\hline & Snort & 5 & 5.56 \\
\hline \multirow[t]{5}{*}{ Start of heroin abuse (Age) } & 12 - 17 years & 19 & 21.11 \\
\hline & 18 - 23 years & 47 & 52.22 \\
\hline & $24-29$ years & 19 & 21.11 \\
\hline & $30-35$ years & 4 & 4.44 \\
\hline & $36-41$ years & 1 & 1.11 \\
\hline \multirow[t]{2}{*}{ Previous attempt to quit } & Yes & 56 & 62.22 \\
\hline & No & 34 & 37.78 \\
\hline
\end{tabular}

\section{Translation Process}

It took approximately two months to finalize the process. Two independent translators had done the initial translation from the English language to the Malay language. The bilingual translators translated the questionnaire into Malay to better reflect the nuances of the target language. The authors of this study were the focus group that made the synthesis.

\section{Validity Analysis}

We emailed the final draft of the TMQ Malay version with the original English scale to experts for content validity. They filled out a form stating whether or not they agreed to the translation of each article and provided comments or alternative translations. To receive feedback on content validity, the researcher created a content validity form adapted from Lim (2007). The form 
contains three components consisting of; i) Item Relevance, ii) Content Coverage, and iii) Item Format. For component i) and ii), the evaluation are using a 5 -point scale of $1=$ Not Suitable, 2 = Less Suitable, 3 = Suitable, 4 = Somewhat Suitable, and $5=$ Very Suitable. For evaluation on component 2, the evaluation scale is; $5=$ Very Comprehensive, $4=$ Somewhat Comprehensive, 3=Comprehensive, 2=Less Comprehensive, and 1=Not Comprehensive. Findings from Table 2 show that the percentage of experts' agreement for the TMQ questionnaire is high and exceeds $80 \%$. These findings indicate that the TMQ questionnaire is acceptable and applicable in the context of this study.

Table 2TMQ instrument content validity

\begin{tabular}{lllll}
\hline Bil. & Component & Expert Panel & Percentage & Results \\
\hline 1. & Item relevance & Expert 1 & 93.1 & Accepted \\
& & Expert & 98.4 & Accepted \\
& Expert 1 & 100 & Accepted \\
2. Content Coverage & Expert 1 & 95 & Accepted \\
& Expert 1 & 90 & Accepted \\
& Expert 1 & 100 & Accepted \\
3. Item Format & Expert 1 & 96.6 & Accepted \\
& & Expert 1 & 100 & Accepted \\
& & Expert 1 & 100 & Accepted \\
\hline
\end{tabular}


Table 3 shows the correlation between sub-scales with overall items exceeding 0.30 , indicating that the discriminant validity of the subscales in TMQ was satisfactory.

Table 3Inter-subscales correlation of TMQ

\begin{tabular}{|c|c|c|c|c|c|c|}
\hline \multicolumn{7}{|c|}{ Correlations } \\
\hline & & TMQ & external & internal & seeking & $\begin{array}{c}\text { confidenc } \\
\mathrm{e}\end{array}$ \\
\hline \multirow[t]{4}{*}{ TMQ } & Pearson & 1 & $.767^{* *}$ & $.960^{* *}$ & $.887^{* *}$ & $.616^{* *}$ \\
\hline & Correlation & & & & & \\
\hline & Sig. (2-tailed) & & .000 & .000 & .000 & .000 \\
\hline & $\mathrm{N}$ & 90 & 90 & 90 & 90 & 90 \\
\hline \multirow[t]{4}{*}{ external } & Pearson & $.767^{* *}$ & 1 & $.705^{* *}$ & $.552^{* *}$ & $.385^{* *}$ \\
\hline & Correlation & & & & & \\
\hline & Sig. (2-tailed) & .000 & & .000 & .000 & .000 \\
\hline & $\mathrm{N}$ & 90 & 90 & 90 & 90 & 90 \\
\hline \multirow[t]{4}{*}{ internal } & Pearson & $.960^{* *}$ & $.705^{* *}$ & 1 & $.826^{* *}$ & $.459^{* *}$ \\
\hline & Correlation & & & & & \\
\hline & Sig. (2-tailed) & .000 & .000 & & .000 & .000 \\
\hline & $\mathrm{N}$ & 90 & 90 & 90 & 90 & 90 \\
\hline \multirow[t]{4}{*}{ seeking } & Pearson & $.887^{* *}$ & $.552^{* *}$ & $.826^{* *}$ & 1 & $.410^{* *}$ \\
\hline & Correlation & & & & & \\
\hline & Sig. (2-tailed) & .000 & .000 & .000 & & .000 \\
\hline & $\mathrm{N}$ & 90 & 90 & 90 & 90 & 90 \\
\hline confidenc & Pearson & $.616^{* *}$ & $.385^{* *}$ & $.459^{* *}$ & $.410^{* *}$ & 1 \\
\hline \multirow[t]{3}{*}{ e } & Correlation & & & & & \\
\hline & Sig. (2-tailed) & .000 & .000 & .000 & .000 & \\
\hline & $\mathrm{N}$ & 90 & 90 & 90 & 90 & 90 \\
\hline
\end{tabular}

**. Correlation is significant at the 0.01 level (2-tailed).

\section{Reliability and Item Analysis}

We calculated it as instructed in the TMQ instruction manual. Table 4 shows the mean scores and standard deviation for all TMQ 26 items. The most frequently endorsed item was item 1, 'I really want to make some changes in my life.' This item is under internal motivation. "I am not sure this program will work for me" was the item under that was endorsed the least. Cronbach's alpha was 0.942. All items, if deleted, would decrease the total scale of Cronbach's alpha. All items correlated with the total scale to a good degree (lowest $r=0.161$ ) except item 13, "I am not sure this program will work for me," with $r=0.082$. inter-item correlations range between 0.101 and 0.588 , as shown in Table 5. 
INTERNATIONAL JOURNAL OF ACADEMIC RESEARCH IN BUSINESS AND SOCIAL SCIENCES

Vol. 11, No. 7, 2021, E-ISSN: 2222-6990 @ 2021 HRMARS

Table 4: Item-total statistics of TMQ

\begin{tabular}{|c|c|c|c|c|c|}
\hline & Mean & $\begin{array}{c}\text { Std. } \\
\text { Deviation }\end{array}$ & $\begin{array}{c}\text { Corrected Item- } \\
\text { Total } \\
\text { Correlation }\end{array}$ & $\begin{array}{l}\text { Squared Multiple } \\
\text { Correlation }\end{array}$ & $\begin{array}{c}\text { Cronbach's Alpha if } \\
\text { Item Deleted }\end{array}$ \\
\hline Q1 & 6.01 & 1.473 & .707 & .700 & .939 \\
\hline Q2 & 5.40 & 1.606 & .729 & .670 & .939 \\
\hline Q3 & 4.40 & 2.065 & .404 & .596 & .943 \\
\hline Q4 & 5.64 & 1.531 & .822 & .834 & .938 \\
\hline Q5 & 5.84 & 1.586 & .843 & .854 & .937 \\
\hline Q6 & 4.92 & 1.874 & .617 & .681 & .940 \\
\hline Q7 & 5.40 & 1.668 & .778 & .880 & .938 \\
\hline Q8 & 5.22 & 1.810 & .708 & .847 & .939 \\
\hline Q9 & 5.56 & 1.447 & .809 & .888 & .938 \\
\hline Q10 & 4.94 & 1.712 & .494 & .571 & .941 \\
\hline Q11 & 5.70 & 1.402 & .817 & .811 & .938 \\
\hline Q12 & 3.61 & 2.097 & .211 & .458 & .946 \\
\hline Q13 & 3.51 & 1.996 & .311 & .439 & .944 \\
\hline Q14 & 5.41 & 1.483 & .691 & .689 & .939 \\
\hline Q15 & 5.70 & 1.561 & .840 & .874 & .937 \\
\hline Q16 & 3.83 & 1.360 & .064 & .334 & .945 \\
\hline Q17 & 5.40 & 1.634 & .781 & .827 & .938 \\
\hline Q18 & 5.11 & 1.679 & .598 & .788 & .940 \\
\hline Q19 & 5.32 & 1.708 & .736 & .806 & .938 \\
\hline Q20 & 5.54 & 1.552 & .778 & .814 & .938 \\
\hline Q21 & 3.58 & 2.000 & .302 & .463 & .944 \\
\hline Q22 & 5.39 & 1.504 & .665 & .742 & .939 \\
\hline Q23 & 5.77 & 1.469 & .752 & .752 & .938 \\
\hline Q24 & 3.97 & 2.143 & .268 & .556 & .945 \\
\hline Q25 & 5.40 & 1.599 & .739 & .807 & .938 \\
\hline Q26 & 5.76 & 1.524 & .825 & .862 & .938 \\
\hline
\end{tabular}


Table 5 Inter-item correlation matrix analysis of TMQ

\begin{tabular}{|c|c|c|c|c|c|c|c|c|c|c|c|c|c|c|c|c|c|c|c|c|c|c|c|c|c|c|}
\hline & Q1 & Q2 & Q3 & $\mathrm{Q} 4$ & Q5 & Q6 & Q7 & Q8 & Q9 & Q10 & Q11 & Q12 & Q13 & Q14 & Q15 & Q16 & Q17 & Q18 & Q19 & Q20 & Q21 & Q22 & Q23 & Q24 & Q25 & $\begin{array}{c}\text { Q2 } \\
6\end{array}$ \\
\hline \multirow{2}{*}{ Q1 } & 1.0 & .62 & .47 & .61 & .67 & .34 & .46 & .40 & .55 & .24 & .60 & .27 & .30 & .46 & .60 & .11 & .57 & .45 & .54 & .53 & .29 & .50 & .58 & .17 & .53 & .65 \\
\hline & 00 & 5 & 9 & 5 & 9 & 6 & 9 & 8 & 1 & 1 & 6 & 1 & 8 & 1 & 8 & 3 & 7 & 4 & 4 & 3 & 2 & 5 & 8 & 5 & 2 & 2 \\
\hline \multirow{2}{*}{ Q2 } & .62 & 1.0 & .31 & .69 & .69 & .48 & .65 & .57 & .64 & .47 & .57 & .13 & .21 & .57 & .69 & .02 & .53 & .40 & .55 & .62 & .13 & .50 & .59 & .10 & .58 & .67 \\
\hline & 5 & 00 & 7 & 4 & 5 & 8 & 7 & 2 & 8 & 4 & 8 & 7 & 2 & 6 & 4 & 6 & 8 & 8 & 0 & 8 & 4 & 7 & 2 & 2 & 0 & 9 \\
\hline \multirow{2}{*}{ Q3 } & .47 & .31 & 1.0 & .36 & .47 & .12 & .26 & .17 & .30 & .02 & .29 & .45 & .10 & .11 & .27 & .10 & .23 & .22 & .27 & .24 & .34 & .15 & .27 & .36 & .24 & .37 \\
\hline & 9 & 7 & 00 & 2 & 2 & 7 & 6 & 1 & 8 & 9 & 8 & 1 & 0 & 1 & 8 & 4 & 8 & 0 & 5 & 7 & 1 & 6 & 2 & 1 & 7 & 4 \\
\hline \multirow{2}{*}{ Q4 } & .61 & .69 & .36 & 1.0 & .82 & .61 & .67 & .60 & .66 & .46 & .70 & .05 & .20 & .58 & .73 & .03 & .71 & .57 & .69 & .65 & .21 & .61 & .70 & .18 & .61 & .73 \\
\hline & 5 & 4 & 2 & 00 & 8 & 7 & 7 & 5 & 9 & 4 & 4 & 8 & 7 & 0 & 1 & 1 & 3 & 1 & 3 & 0 & 5 & 7 & 7 & 8 & 9 & 8 \\
\hline \multirow{2}{*}{ Q5 } & .67 & .69 & .47 & .82 & 1.0 & .56 & .69 & .62 & .68 & .46 & .72 & .18 & .23 & .55 & .75 & .10 & .60 & .51 & .68 & .74 & .28 & .53 & .61 & .21 & .61 & .72 \\
\hline & 9 & 5 & 2 & 8 & 00 & 3 & 1 & 3 & 5 & 9 & 7 & 8 & 5 & 8 & 7 & 8 & 1 & 7 & 2 & 7 & 0 & 9 & 1 & 3 & 9 & 8 \\
\hline \multirow{2}{*}{ Q6 } & .34 & .48 & .12 & .61 & .56 & 1.0 & .67 & .65 & .66 & .54 & .62 & 05 & .20 & .51 & .51 & 17 & .50 & .41 & .51 & .57 & .03 & .43 & .54 & .06 & .46 & .50 \\
\hline & 6 & 8 & 7 & 7 & 3 & 00 & 5 & 5 & 7 & 2 & 8 & $\begin{array}{r}.05 \\
6\end{array}$ & 3 & 7 & 4 & 7 & 6 & 4 & 0 & 5 & 6 & 7 & 8 & 6 & 8 & 9 \\
\hline \multirow{2}{*}{ Q7 } & .46 & .65 & .26 & .67 & .69 & .67 & 1.0 & .85 & .85 & .58 & .73 & .10 & .21 & .69 & .70 & & .58 & .34 & .49 & .70 & .17 & .46 & .58 & .15 & .54 & .68 \\
\hline & 9 & 7 & 6 & 7 & 1 & 5 & 00 & 6 & 7 & 3 & 4 & 3 & 8 & 1 & 7 & $\begin{array}{r}8 \\
9\end{array}$ & 8 & 5 & 1 & 5 & 6 & 1 & 4 & 8 & 2 & 4 \\
\hline \multirow{2}{*}{ Q8 } & .40 & .57 & .17 & .60 & .62 & .65 & .85 & 1.0 & .79 & .57 & .66 & .05 & .27 & .62 & .62 & 1 & .55 & .42 & .42 & .62 & .07 & .40 & .52 & .15 & .61 & .56 \\
\hline & 8 & 2 & 1 & 5 & 3 & 5 & 6 & 00 & 8 & 3 & 0 & 6 & 3 & 3 & 4 & 3 & 9 & 4 & 4 & 1 & 3 & 5 & 7 & 5 & 3 & 6 \\
\hline \multirow{2}{*}{ Q9 } & .55 & .64 & .30 & .66 & .68 & .66 & .85 & .79 & 1.0 & .58 & .74 & .11 & .31 & .67 & .71 & & .57 & .32 & .49 & .68 & .26 & .44 & .63 & .30 & .59 & .66 \\
\hline & 1 & 8 & 8 & 9 & 5 & 7 & 7 & 8 & 00 & 0 & 8 & 6 & 3 & 8 & 7 & 10 & 5 & 1 & 5 & 5 & 1 & 2 & 8 & 3 & 3 & 9 \\
\hline Q1 & .24 & .47 & .02 & .46 & .46 & .54 & .58 & .57 & .58 & 1.0 & .58 & .01 & .09 & .46 & .51 & & .39 & .20 & .24 & .52 & .00 & .41 & .37 & 17 & .36 & .46 \\
\hline 0 & 1 & 4 & 9 & 4 & 9 & 2 & 3 & 3 & 0 & 00 & 3 & 9 & 7 & 1 & 9 & 1 & 0 & 2 & 8 & 3 & 0 & 0 & 9 & 4 & 1 & 4 \\
\hline Q1 & .60 & .57 & .29 & .70 & .72 & .62 & .73 & .66 & .74 & .58 & 1.0 & .19 & .18 & .60 & .75 & .05 & .67 & .47 & .57 & .72 & .19 & .63 & .60 & .16 & .57 & .79 \\
\hline 1 & 6 & $8 \mid$ & 8 & 4 & 7 & 8 & 4 & 0 & 8 & 3 & 00 & 3 & 0 & 6 & 9 & 0 & 6 & 3 & 6 & 7 & 5 & 1 & 9 & 1 & 0 & 1 \\
\hline
\end{tabular}


INTERNATIONAL JOURNAL OF ACADEMIC RESEARCH IN BUSINESS AND SOCIAL SCIENCES

Vol. 11, No. 7, 2021, E-ISSN: 2222-6990 @ 2021 HRMARS

\begin{tabular}{|c|c|c|c|c|c|c|c|c|c|c|c|c|c|c|c|c|c|c|c|c|c|c|c|c|c|c|}
\hline Q2 & .53 & .58 & .24 & .61 & .61 & .46 & .54 & .61 & .59 & .36 & .57 & .02 & .22 & .57 & .72 & .13 & .66 & .66 & .65 & .61 & .13 & .69 & .63 & .10 & 1.0 & .71 \\
\hline 5 & 2 & 0 & 7 & 9 & 9 & 8 & 2 & 3 & 3 & 1 & 0 & 7 & 4 & 9 & 4 & 4 & 5 & 5 & 2 & 3 & 8 & 1 & 8 & 6 & 00 & 8 \\
\hline Q2 & .65 & .67 & .37 & .73 & .72 & .50 & .68 & .56 & .66 & .46 & .79 & .12 & .08 & .66 & .81 & .13 & .71 & .54 & .63 & .74 & .16 & .70 & .72 & .10 & .71 & 1.0 \\
\hline 6 & 2 & 9 & 4 & 8 & 8 & 9 & 4 & 6 & 9 & 4 & 1 & 5 & 2 & 1 & 9 & 2 & 2 & 2 & 1 & 6 & 1 & 9 & 7 & 1 & 8 & 00 \\
\hline
\end{tabular}




\section{Discussion}

The present study aimed to translate and validate the TMQ into Malay in a Malay speaking group opioid use disorders in Methadone treatment. Evidence for validity and reliability of the Malay TMQ was found in the translation, content validity, and reliability analysis in internal consistency. Firstly, The TMQ has minimal empirical evidence to support validity and reliability. However, we found that these four subscales supported predictive validity when using the TMQ to assess client motivation for substance abuse treatment, as Cahill et al. (2003) suggested. In addition, Ryan. Plant \& O'Malley (1995) found that convergent validity was supported by assessing the TMQ scores, problem severity, and clinicians' ratings of client motivation for treatment. Secondly, in our study, we found the corrected item-total correlation values were higher than 0.30 and significant in the degree of $p<0.001$. The only correlation between item 13th and all items on the scale was low ( $r=0.0082)$. This item is under the subscale Confidence in treatment. A similar study with Evren et al (2006) found a low correlation between Confidence in treatment and the 14th item included in that subscale. This issue may be due to several items in subscale confidence used reverse item which impacts the internal consistency. Subsequent studies suggest that mixing positively and negatively worded items can adversely affect measure consistency/unidimensionality (Ping, 2004).

Thirdly, the TMQ's internalized motivation calculation is made from the averaging of 11 questions, while the externalized motivation calculation is made from averaging four questions. This may make the externalized motivation calculation less precise. In addition, the externalized motivation can quickly vary depending on the cognitive functioning associated with the present environmental influences. Fourthly, TMQ is a measure developed on an outpatient sample and thus may not be sensitive enough to fully capture aspects of motivation in individuals appropriate for residential treatment. Using this measure with other samples, including additional outpatient and residential groups, would offer additional information regarding the validity of this measure. We suggest utilizing multiple measures, including information about patients from those working with them in treatment, spouses, family members, and friends, to better understand this measure and motivation in general.

\section{Conclusion}

The TMQ is a commonly used tool with a few translations worldwide. The Malay version of the TMQ is a valid and reliable measure to assess treatment motivation in a Malay sample. We hope our study will encourage researchers and practitioners to conduct more studies in Malaysia regarding treatment motivation in other modalities. However, our study has several limitations. Initially, the study was carried out under opioid use disorder patients under methadone treatments; therefore, it cannot be generalized. Second, it would be better if the reliability was examined through test-retest and not limited to the internal consistency tests. Third, we did not do convergent validity by comparing the scale to another gold standard. 


\section{Reference}

Almeman, A. A., Ismail, R., \& Mohamad, N. (2017). Methadone Maintenance Therapy (MMT) in Malaysia: An observational clinical study. Australasian Medical Journal 10(4): 314.

American Psychiatric Association. (2013). Diagnostic and statistical manual of mental disorders: DSM-5 (Vol. 10). Washington, DC: American Psychiatric Association.

Ayres, R., Ingram, J., Rees, A., Neale, J., Beattie, A. \& Telfer, M. (2014). Enhancing motivation within a rapid opioid substitution treatment feasibility RCT: a nested qualitative study. Substance Abuse Treatment, Prevention, and Policy 9(1): p.44.

Beaton, D. E., Bombardier, C., Guillemin, F., \& Ferraz, M. B. (2000). Guidelines for the process of cross-cultural adaptation of self-report measures. Spine, 25(24), 3186-3191.

Bulut, S., \& Bozkurt, Í. (2019). The effect of treatment motivation levels on patients sent to a conditional substance abuse treatment program. Universitas Psychologica, 18(1), 1-16.

Cahill, M. A., Adinoff, B., Hosig, H., Muller, K., \& Pulliam, C. (2003). Motivation for treatment preceding and following a substance abuse program. Addictive behaviors, 28(1), 67-79.

Chan, G. H., Lo, T. W., Tam, C. H., \& Lee, G. K. (2019). Intrinsic motivation and psychological connectedness to drug abuse and rehabilitation: The perspective of selfdetermination. International Journal of Environmental Research and Public Health 16(11): 1934.

Chan, G. H., Lo, T. W., Tam, C. H. \& Lee, G. K. (2019). Intrinsic motivation and psychological connectedness to drug abuse and rehabilitation: The perspective of selfdetermination. International Journal of Environmental Research and Public Health 16(11): 1934.

Deci, E. L., \& Ryan, R. M. (1987). The support of autonomy and the control of behavior. Journal of personality and social psychology, 53(6), 1024.

Deci, E. L., \& Ryan, R. M. (2000). The" what" and" why" of goal pursuits: Human needs and the self-determination of behavior. Psychological inquiry, 11(4), 227-268.

Dillon, P. J., Kedia, S. K., Isehunwa, O. O., \& Sharma, M. (2020). Motivations for treatment engagement in a residential substance use disorder treatment program: A qualitative study. Substance Abuse: Research and Treatment, 14, 1178221820940682.

Evren, C., Saatcioglu, O., Dalbudak, E., Danismant, B. S., Cakmak, D., \& Ryan, R. M. (2006). Factorial structure and reliability and validity of Turkish version treatment motivation questionnaire (TMQ) in alcohol dependents. Journal of Dependence, 7(3), 117-122.

Hong, N. A., Prisca, Z., Hien, H., Thuc, D. C., \& Nhan, N. T. (2017). Factors determining dropping out from treatment among methadone clients: a qualitative study in Can Tho City, Vietnam. HIV \& AIDS Review. International Journal of HIV-Related Problems, 16(1), 3239.

Ibrahim, F., Samah, B. A., Talib, M. A., \& Sabran, M. S. (2012). Drug Addicts and the High Risk Situations of Relapse. e-Bangi, 9(1).

Hin, L. C. (2007). Penyelidikan pendidikan: Pendekatan kuantiatif dan kualitatif. Selangor: McGraw- Hill (Malaysia).

Matsumoto, D. (1996). Culture and psychology. Pacific Grove, CA: Brooks/Cole.

Melemis, S. M. (2010). I Want to Change My Life: How to Overcome Anxiety, Depression, \& Addiction. Modern Therapies.

Miller, W. R., \& Carroll, K. M. (Eds.). (2011). Rethinking substance abuse: What the science shows, and what we should do about it. Guilford Press. 
Millere, A., Pūce, A., Millere, E., Zumente, Z., Sudraba, V., Deklava, L., Millere, I., Caune, L., \& Vagale, A. (2014). Treatment motivation factor analysis of patients with substance use disorders in Latvia. Procedia-Social and Behavioral Sciences, 159, 298-302.

Mohamad, N., Ismail, R., Latif, A., Zubaidi, A., Mohamad, M., \& Toriman, M. E. (2014). Terapi Penggantian Metadon Penderitaan Kebergantungan Opioid yang boleh diubati. Terengganu: Penerbit Universiti Sultan Zainal Abidin.

Nunnally, J. C. (1994). Psychometric theory 3E. Tata McGraw-hill education.

Ping Jr, R. A. (2004). On assuring valid measures for theoretical models using survey data. Journal of business research, 57(2), 125-141.

Robson, N., Rashid, R., Nazar, M., and Habil, H. (2015). Treating heroin addiction: Bridging the past and future-a Malaysian experience. Asia-Pacific Psychiatry, 7(1), pp.121-125.

Ryan, R. M., Plant, R. W., \& O'Malley, S. (1995). Initial motivations for alcohol treatment: Relations with patient characteristics, treatment involvement, and dropout. Addictive behaviors, 20(3), 279-297.

Salleh, M. J. (2012). Permasalahan Penagihan Dadah: Tinjauan Di Pusat Serenti Selangor. In: International Seminar on Community Development - SAPKO 2012, 7 to 9 April 2012, Kuala Terengganu.

Scherbaum, N., \& Specka, M. (2008). Factors influencing the course of opiate addiction. International Journal of Methods in Psychiatric Research, 17(S1), S39-S44.

Wemm, S. E., \& Sinha, R. (2019). Drug-induced stress responses and addiction risk and relapse. Neurobiology of stress, 10, 100148.

Wild, T. C., Yuan, Y., Rush, B. R., \& Urbanoski, K. A. (2016). Client engagement in legallymandated addiction treatment: A prospective study using self-determination theory. Journal of Substance Abuse Treatment 69: 35-43. 